\title{
Sustainable cost management in the supply chain: A case analysis
}

\author{
Reşat Karcioğlu' ${ }^{1}$ \\ Seyhan Öztürk ${ }^{2}$ \\ 1 Prof. Dr., Atatürk University, FEAS, Department of Administration, Turkey, e-mail: rkarcı@ata.uni.edu.tr \\ 2 Doç. Dr., Kafkas University, FEAS, Department of Administration, Turkey, e-mail: seyhan87ozturk@gmail.com
}

\begin{abstract}
In today's constantly developing and changing world, businesses strive for superiority in various areas to survive and create competitive advantage. Businesses that can integrate sustainability into their activities can be more successful in this sense and take a step ahead of their competitors. The supply chain, which covers all the activities carried out in the process starting with the supply of materials until they are delivered to the end consumer, is another area where competition has been intense recently. To adapt to the order in the global environment, businesses need to adopt a different cost management approach while building their supply chains. While the cost management approach in earlier times only dealt with the management of costs arising within the enterprise, cost reduction processes in the modern age not only include the internal costs but also all the costs incurred throughout the supply chain outside the enterprise. Therefore, to achieve success and create a competitive advantage, the need to manage costs in an integrated manner arises. In this context, this study tackles the issue of sustainable cost in the retailing sector, which is an important element of the supply chain and has special importance in economic crises, with particular focus on Migros Trading Joint Stock Company (Migros Co.), one of the forty largest retail companies in the World. By analyzing the sustainability reports published by the company between 2016-2020, the factors affecting sustainability in retailing, sustainable value networks, and their sub-titles are examined in detail. According to the results obtained, in the specific case of Migros T.A.Ş., continuously developing the awareness of sustainability in the retail sector and particularly adopting sustainable cost management are very important factors for business success.
\end{abstract}

Keywords: Sustainable cost management, Supply chain management, Retailing sector

JEL codes: M40 


\section{INTRODUCTION}

Technological advances, developments in information and communication tools, and the increase in the number of large-scale enterprises interacting with the global environment have paved the way for a highly competitive environment. In the order of these dynamics, to maintain their existence, businesses attempt to build competitive advantage in different areas, especially to make a difference in cost reduction. Recently, this situation creates added value for businesses that care about sustainability both in their activities and in their management approach and gives them an overwhelming advantage compared to other competitors. This is valid for the supply chain elements of the enterprises. Competitive environments no longer reflect the interaction between businesses but rather the competition between supply chains. In the retailing sector, which is considered the most important element of supply chains, developing and sustaining sustainability awareness is a very important factor for success (Lukic, 2013:268).

In this context, the study aims to examine the issue of sustainable cost management in the supply chain, especially in retailing, and to apply it to the selected case. Due to the importance of the subject, the concepts of supply chain management, cost management, strategic cost management, and especially sustainable cost management are elaborately explained. Cost management and its techniques in the supply chain are also discussed in detail. Finally, to address the issue in the context of the retail sector, by analyzing the sustainability reports published by Migros Co. between 2016-2020, the factors affecting sustainability in retailing, sustainable value networks, and their sub-titles are examined. According to the results obtained, in the specific case of Migros Co., continuously developing the awareness of sustainability in the retail sector and especially, adopting sustainable cost management are very important factors for business success.

\section{SUPPLY CHAIN MANAGEMENT}

The concept of "Supply Chain", which has been used very frequently in recent times, has various definitions. Technically, the supply chain is the network of transactions that covers the process which starts with material procurement, goes on to transform these materials into a product or products, and in the next step, delivers the product(s) to customers through distribution channels. This network fulfills all the functions of supplying materials, transforming them into intermediate and finished products, and distributing finished products to customers step by step (Eymen, 2007: 7). The supply chain can also be defined as the set of entities including suppliers, logistics service providers, manufacturers, distributors, and resellers through which materials, products, and information flow (Kopczak, 1997: 226). In short, a series of activities to add value to customers by using resources constitute the supply chain (Yao \& Lui, 2006: 54).

The supply chain begins with the purchase and supply phase required for the product that is expected to be produced and sold. It then continues with inventory management and warehouse management to support sales. This chain ends with the distribution of products to customers. In the supply chain, materials pass from raw material sources to a production process that converts them into semi-finished products. The semi-finished products are combined to form the finished products in the next stage. The products obtained are first transferred to the distribution centers, and from there to the sellers and customers (Yildırım, 2009: 178).

To define the supply chain most comprehensively; It includes all elements that contribute directly or indirectly to the fulfillment of customer demands. At this point, not only the producer or the supplier but also the customer, retailer, logistician, and even the warehouseman constitutes a link in this chain (Chopra \& Meindil, 2007:4). From this aspect, the supply chain explains the reciprocal relationship between all the units that make up the rings of the chain (Heizer \& Render, 1996:416).

Recently, with the increase in social awareness about the consumption of natural resources, the concept of sustainable supply chain has emerged (Sar1 et al., 2017: 477). The sustainable supply 
chain is defined as a system that minimizes the environmental damage caused by the processes of packaging, transportation, packing, storage, etc. during the delivery of the product from the producer to the end consumer. Supply chain sustainability is the promotion of environmental, social, and economic impacts throughout the life cycle of products and services. A sustainable supply chain aims to provide, protect and develop long-term environmental, social, and economic values for all stakeholders involved in the delivery of products and services to the market (Karakoç et al, 2020:217).

All supply chains include three basic elements; suppliers, manufacturers, and customers. Most of the supply chains include distributors and retailers in addition to these three key elements. These elements generally work in coordination; products and services flow from sources of supply to sources of demand while information and payments flow in the reverse direction. Here, the goal is to create superior customer value and satisfaction as a result of the operations of the supply chain elements (Smith \& Lockamy, 2000: 69).

Supply chain management, which is a broader concept, is a management philosophy that covers the management of materials and products from basic raw material procurement to the final product (including possible recycling and reuse) and focuses on how to utilize technology and capabilities to support competitive advantages (Tan et al., 1998: 2). It is the joint management of information, material, and money flow, which aims to deliver the product to the customer at the lowest cost for all supply chain links at the right time, place, and price. In other words, it is the use of strategies and business models that increase customer satisfaction by ensuring that the basic business processes in the chain operate together (Sar1 et al., 2017: 477).

Ingeneral, supply chain managementisconcerned with the control of information flows regarding the value offered to the customer, transformation of materials into products to increase customer satisfaction, and the distribution of finished products to customers and markets through the most appropriate channels (Öztürk, 2016: 18). For businesses that mainly focus on quality, a correct understanding of supply chain management processes depends on designing these processes correctly. Problems in the quality of production and errors in production often arise from the designing of these processes. The philosophy of supply chain management is a process-oriented strategy aiming for high quality simultaneously with low cost. Therefore, the processes that make up the supply chain management have highly critical importance for the success of the business (Karaman, 2016).

Although supply chain management is defined from various perspectives, it stands out as an application that basically aims to improve operational performance (Lee et al., 2018: 16) 2018: 16). The philosophy of this approach serves to improve organizational performance and quality performance through logistics, operations and materials management, marketing, purchasing, and information technology functions (Li et al., 2006: 107)

Supply chain management is concerned with coordinating material, information, and financial flows within a network of suppliers, manufacturers, distributors, and customers. An effective supply chain management is possible by coordinating these flows appropriately within and between businesses. The supply chain's ability to provide goods and services at the desired quality and price to the end customer also requires effective cost management (Akgün, 2004: 68)

In short, supply chain management refers to the management of material/product, money, and information between suppliers, manufacturers, distributors, retailers, and customers in the value chain. In this context, it is possible to list the main objectives of supply chain management as follows (Özdemir, 2004: 89):

- "Increasing customer satisfaction"

- "Reducing cycle time"

- "Enabling the reduction of inventory and inventory-related costs,"

- "Reducing product defects,"

- "Reducing the operating cost." 


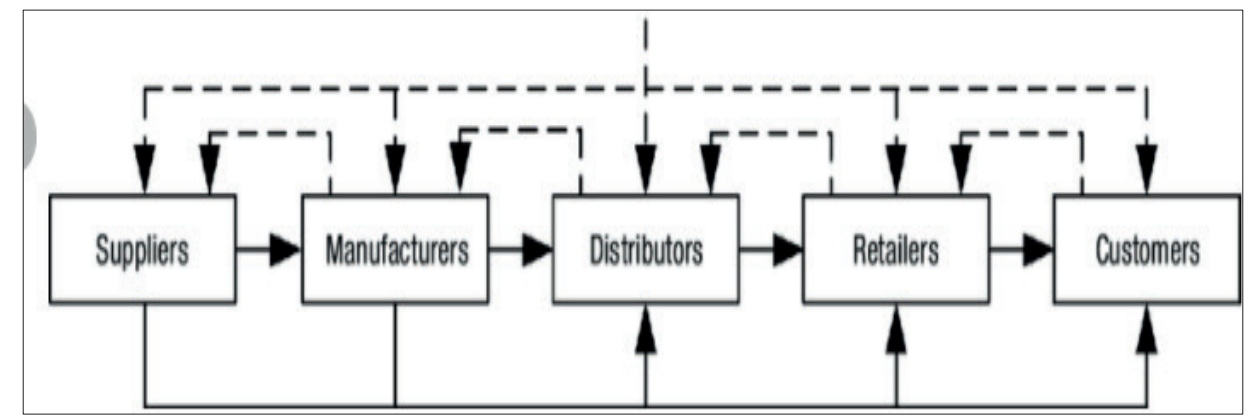

Information Flow

Material Flow

Figure.1. Supply Chain Management

Source: Öztürk, 2016: 18

As seen in Figure 1, supply chain management provides the coordination of material, information, and cash flows in the supplier, manufacturer, wholesaler, retailer, and customer chain as a whole. In addition, it focuses on how the company can transform its supply processes and the technologies used in these processes into a competitive advantage (Lee \& Billington, C. 1992: 33).

The objectives of supply chain management include increasing profitability, customer service performance, and market share, as well as reducing costs in general and inventory costs in particular. Supply chain costing is based on an approach that establishes performance values for the set of activities that make up the supply chain on a cost basis. The biggest problem of this approach is that enterprises do not disclose their cost information to other elements of the chain. Therefore, the following conditions must be met for supply chain costing to work effectively (Sevim \& Elmac1, 2007:103):

- "The business must know exactly the costs associated with its activities."

- "The business must share this information with other enterprises with which it has direct prospective and retrospective relationships."

- "Necessary parts of this information should also be available to other links of the chain."

In the traditional procurement and purchasing process, the interactions of suppliers and customers were based on competition rather than cooperation. Today, this situation is reversed and because of the awareness that all the costs related to the product are added to the sales price given to the final buyer, businesses are looking for ways to increase profitability and reduce costs by cooperating with the links in the supply chain rather than seeing them as a competitor. The point that should not be forgotten here is; real competition should be between supply chains and supply chains, not between businesses and businesses (Lambert \& Cooper, 2000: 65). At this point, the dissemination of cost management efforts along the supply chain line is possible by extending the strategic cost management processes to the external environment of the enterprise, including the suppliers and customers outside the enterprise. Businesses that plan their cost management programs together with their customers and suppliers gain a great advantage compared to their competitors by creating synergy both among themselves and with their supply chain partners (Slagmulder, 2002: 79).

As a result, to keep up with current change and development, supply chain creators have placed emphasis on making a difference in cost management practices. While the traditional cost management approach focuses only on the management of costs within the business, modern cost reduction efforts do not only deal with the costs incurred in the business but also all the costs arising from the factors outside the business. Therefore, to achieve success and create a competitive advantage, costs must be managed in an integrated manner (Rena, 2010: 84).

\section{COST MANAGEMENT - STRATEGIC COST MANAGEMENT}

It is seen that income and cost data come to the fore when it is necessary to take decisions due to anomalies that occur on specific occasions. 
Considering this, the importance of the concept of cost increases more and the need to obtain this information in an accurate manner arises. Cost management on the one hand helps to determine the costs, on the other hand, it monitors and controls the changes in the cost elements. Thus, efficiency is ensured in the activities of businesses such as preventing waste and performance control (Alkan, 2001: 179-180).

A significant part of the information that the top management of the business needs while performing the planning, control, and decisionmaking functions is provided from the cost information. Therefore, business managers are expected to have information about costs and all factors affecting costs (Otlu \& Karaca, 2005: 246).

It is also possible to explain cost management as providing information that will help managers to use resources efficiently in the production of products or services that can be competitive in terms of timing, cost, quality, and functionality in global markets. In other words, it is to act with an integrated system understanding by providing interaction between production, raw material management, research and development, engineering, and financing functions in the business (Avc1, 2014: 25).

The preparation and analysis of cost accounting information related to business strategies, especially the use of all resources of the business and the relative levels of cash flow, market shares, quantities, prices, and real costs, is explained by the concept of strategic cost management (Yağmurlu, 2009: 28).

Strategic cost management stands out as an approach that deals with the conditions created by the global competition order with a broader and longer-term perspective, integrating strategic planning and strategic cost analysis (Karcioğlu, 2000: 72-73).

Strategic cost management also helps to develop a sustainable competitive position in the competitive advantage of businesses and to provide continuous and increasing success for the business. It refers to the application of cost management techniques to continuously improve the strategic positions of enterprises and reduce their costs. It is to manage financial objectives for cost advantage both in the short term and in the long term. A clear understanding of a firm's cost structure is also beneficial in terms of creating a sustainable competitive advantage (Yalçın, 2006: 17-18).

\section{COST MANAGEMENT IN THE SUPPLY CHAIN}

Developments and changes in the global environment have transformed inter-firm competition into competition between supply chains. Therefore, it becomes increasingly difficult for the enterprises that make up the supply chain to distinguish themselves from the other rings of the chain and gain competitive power only in the areas where they are superior. "Because today's business world environment requires the supply chains to act as a single organization, yet encompassing more than one business. For this reason, the most important quality in the supply chain is the sharing of information" (Akgün, 2004; 72). On the basis of cooperation in supply chains, problems arise when up-to-date, complete, and fast information flow from customers to suppliers cannot be provided simultaneously with the material flow in the opposite direction. The most common problem among the problems experienced is the "Information Erosion" problem, which is explained as the discrepancy in demand and delivery times. When faced with such a problem, in each link of the supply chain that moves away from the customer, defects in order quantities and deliveries occur and these defects grow in each new link towards the suppliers. The effects of information erosion on supply chain performance can be explained as follows (Chopra \& Meindl, 2004; 363):

- "Production costs increase."

- "Inventory costs go up."

- "Replenishment time increases."

- “Transport costs increase."

- "Loading and fulfillment costs increase".

- "The availability level of the product decreases." 
- "Profitability decreases."

The importance of cost management in the supply chain is associated with the fact that the costs of distribution within the supply chain are kept separate from the costs incurred in the production process of the business.

This is one of the situations that once again reveals the importance of the supply chain. Because, achieving the targeted profitability in parallel with the price determined in the market as part of cost management and the implementation of necessary cost reductions are possible by reducing the costs not only at the beginning of the production but also in the other elements of the supply chain (Türker et al., 2005: 462).

Several studies examining the relationship between supply chain management and financial performance reveal that decreasing costs through strategic supply chain management increases financial performance. In addition, there are studies with opposite views arguing that strategic supply chain management increases costs on the grounds that it creates many different cost elements and therefore negatively affects financial performance (Ortas et al., 2014). To adapt to the global environment, businesses need high performance in supply chain management on the one hand, and on the other hand, they feel the need to create cost reductions (Jakhar, 2015: 393). For this reason, it is necessary to use techniques that will minimize costs in supply chain management. Having said that, the inclusion of cost and benefit measures in the value chain reveals the performance more clearly (Tsai \& Hung, 2009: 5001).

In order to make the supply chain as efficient as possible, strategic cost management encourages all businesses within the value chain to create competitive advantage through cost reduction or product differentiation (Fayard et al., 2007:8). In addition, strategic cost management includes responding to potential cost pressures made by customers at all levels of the supply chain as well as identifying the causes of costs. In a broad sense, strategic cost management is seen as an

Table 1. "Cost Management Techniques and Applications in Supply Chain"

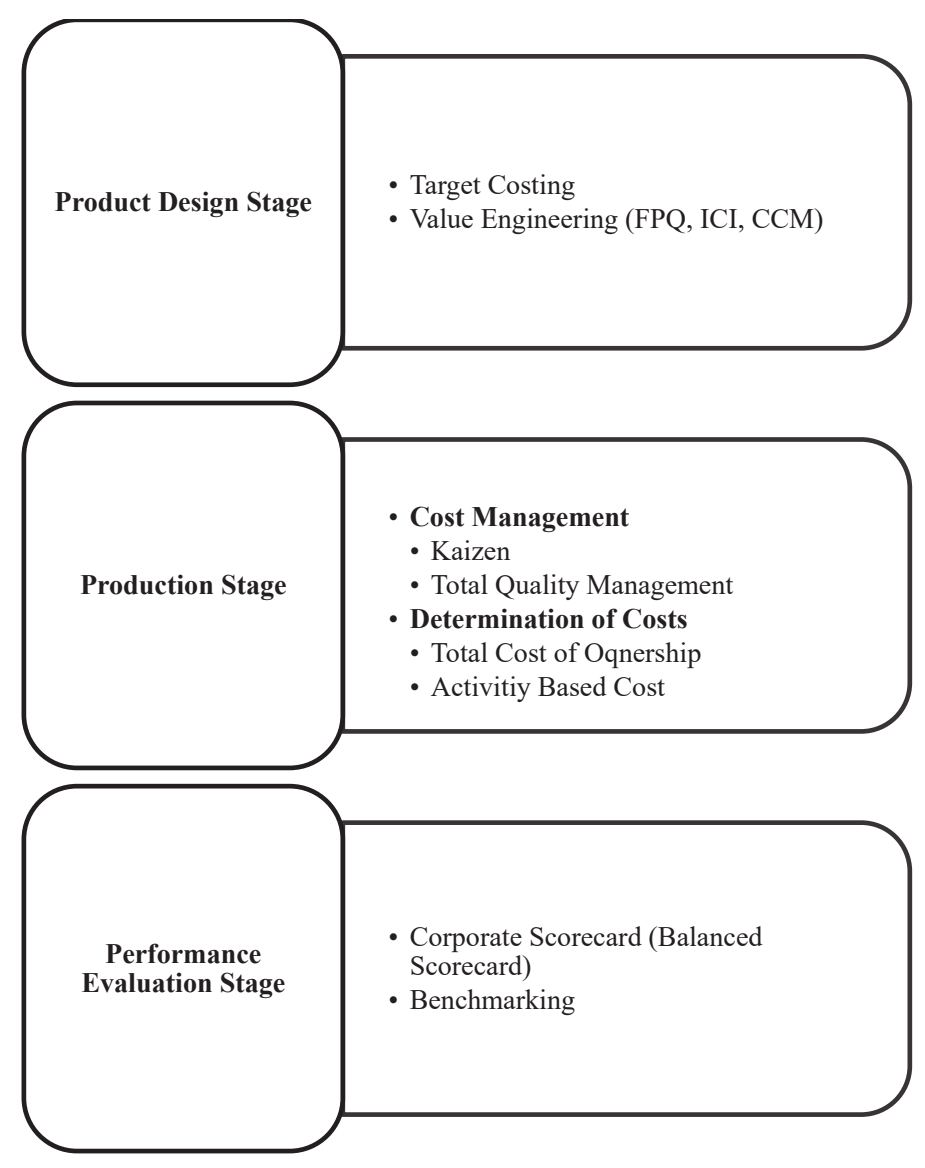


Table 1. more.."Cost Management Techniques and Practices Related to Relationships in the Supply Chain"

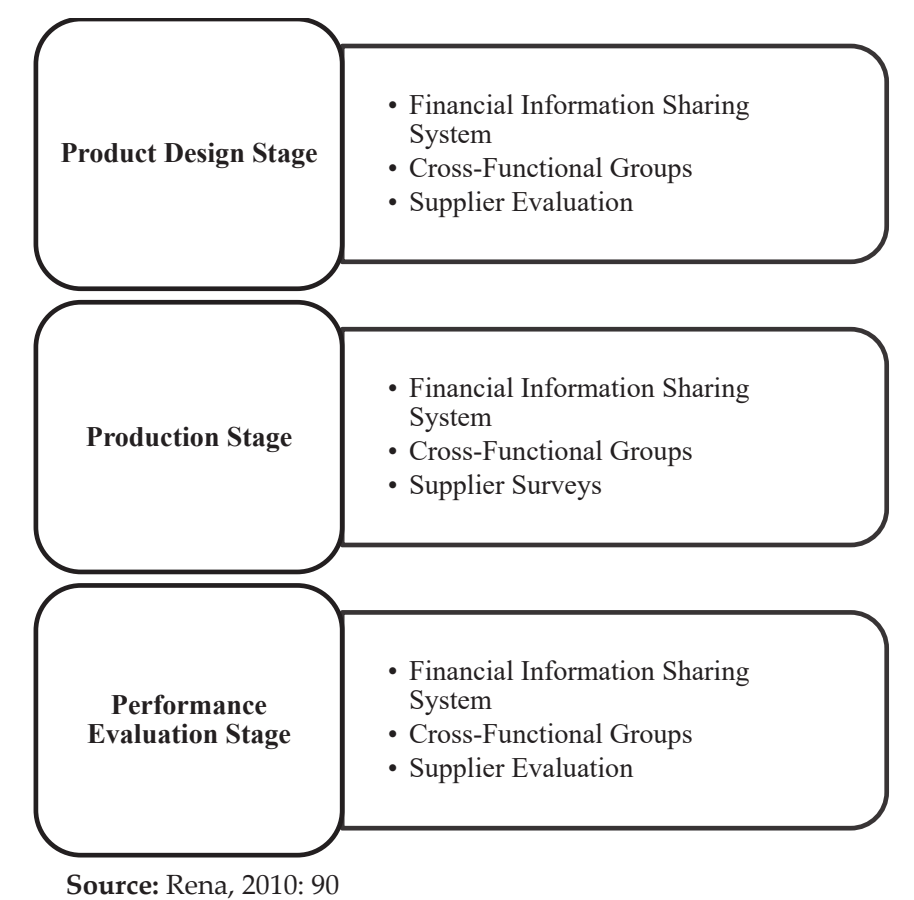

approach that requires a holistic cost perspective across all links of the supply chain (Ellram, 2008: 181).

Cost management in the supply chain is a broader concept that includes managing the interrelationships of all elements in the supply chain and the costs arising from them, rather than the cost management efforts within the enterprise itself (Rena, 2010: 88). Therefore, strategic cost management needs to maintain cost management as a whole by expanding the scope of the techniques used in the supply chain and cost management approaches applied within the enterprises to include both buyers and suppliers (Cooper \& Slagmulder, 2004: 6).

In Table 1, "the techniques and practices used in the evaluation of the strategic cost management approach throughout the supply chain are explained by evaluating the product and relationship dimensions. It is seen that each subdimension requires different techniques and applications during the design and production stages of the products and the performance evaluation of these stages" (Rena, 2010: 90).

There are different methods used for cost management in the supply chain. These methods can be listed as direct activity-based costing, product profitability, total cost of ownership, effective consumer response, kaizen costing and target costing (Akgün, 2004; 72). Among these methods, especially the kaizen costing method is based on quality. It focuses on continuously improving both the production process and costs. When they are used together with target costing, which aims to shape the costs in the product design step, it contributes to cost reduction throughout the life cycle of the product, from product design to after-sales services (Özkan \& Aksoylu, 2002: 49-). In addition, while performing cost management, target costing and activity-based costing can be substituted for each other or used simultaneously with each other. "The reason for this situation is that supply chain management should not be considered synonymous with logistics alone or it should not be seen solely as technology" (Lysons, 2000: 7071).

\section{SUSTAINABLE COST MANAGEMENT IN RETAIL}

In the retail sector, which has made significant developments in recent years, competition has increased rapidly in parallel with the technological developments and the marketing approach that changed its focus from the product to the consumer. Retailing is defined as all of the actions taken for the direct sale of goods and 
services to the end consumer for both individual and family use (Mucuk, 2014: 285). Retailers take place in the logistics part, which constitutes an important link of the supply chain. They provide many benefits especially to the consumers, who are the last link, as they play an intermediary role between the producer and the end consumer. In this context, retail businesses enable consumers to buy the goods and services they need where they want (place utility) and when they want (time benefit); they transfer the ownership of goods and services by credit card deferred sales (property benefit); and they provide additional services such as assembly or delivery of the purchased product and service to the consumer address (shape benefit)" (Onurlubaş \& Dinçer, 2017: 63).

In addition to these benefits, retail businesses are also important customers for many manufacturing companies that act as an intermediary between the producer and the final consumer. Thanks to local suppliers, retail businesses produce their products at a much lower cost and sell them at more affordable prices compared to the manufacturers. Thus, they have become an important competitor of the enterprises and this situation has increased the competition in the retail sector (Deste \& Halifeoğlu, 2019:753).

Sustainabilityisaconceptthathelpstosignificantly increase the successful performance of the retail industry. Sustainable cost management is one of the key factors affecting retail business success. Recently, the development of green practices help retailers improve their financial performance and achieve significant cost savings globally. In retailing, sustainable cost management is also important from the economic aspect. This is because retailers prefer "cost reduction" as the primary way to achieve targeted performance. The following are various ways to be successful in retail, in other words, to achieve sustainable cost savings (Lukic, 2013:262):

- Determination of priority targets,

- Involving senior managers and accountants in the process,

- A strong approach to the project
- Tactical and strategic changes,

- Inclusion of all relevant business functions,

- Continuous improvement of sustainable cost management and the development of this culture.

\section{MIGROS COMPANY CASE ANALYSIS}

In this section, the issue of sustainable cost in the retailing sector, which is an important element of the supply chain, is addressed in the case of Migros Co., one of the forty largest retail companies in the world. Looking at the main strategies of Migros Co., core strategies of the company are listed as follows (https:// www.migroskurumsal.com/about us/strateji-vetargets, Access date: 29.11.2021):

- Creating a unique shopping experience

- Sustainable growth

- Improving operational efficiency

- Boosting household reach

It is seen that the company attaches importance to sustainability, especially to sustainable growth and development, as it is also among its strategies. By analyzing the sustainability reports published by the company between 2016-2020; The factors affecting sustainability in retailing, sustainable value networks, and their sub-titles are examined in detail. In this context, hypotheses are generated and results and evaluations related to the analysis of the data are presented.

While generating hypotheses and analyzing the case study, Lukic (2013)'s study on Walmart was used.

\subsection{Research Hypotheses and Method}

The hypotheses of the research are as follows:

H1: Sustainable costs are a crucial factor for business success in modern retail, especially during the economic crisis.

H2: It is necessary to continually develop retailers' "awareness of sustainability" about 
the importance of more efficient sustainable cost management to achieve target performance.

The method of the research is qualitative data analysis. The data in question are the sustainability reports published by Migros Co. between 2016 and 2020. These reports were analyzed using the MAXQODA Analytics Pro 2020 software.

\subsection{Results of the Research}

Sustainability has three dimensions; environmental, social, and economic. Accordingly, when these dimensions of sustainability in retailing are evaluated within the scope of this analysis; these three dimensions and their sub-factors in Table 1 were reached.

According to Table 1., in the case of Migros Co., factors such as green building design, renewable energy, and stakeholder education are given priority in the environmental dimension of sustainability in the retail sector. In the social dimension; it is seen that importance is given to human rights, diversity, and trade fairs. In the economic dimension; shareholder value, financial targets, and corporate governance stand out as the most valued sub-factors.

Sustainable value networks are shown in Table 2. It is seen that Migros Co. implements sustainable cost management and has an adequate sustainable value network. In order to increase their operational and financial performance and to create added value, global and local retail companies adopt value networks that attach importance to renewable energy, zero waste, and sustainable products. It is seen that they prioritize the issues of greenhouse gas, using alternative fuels, and building green offices in the renewable energy category. The zero-waste approach focuses on operations, packaging, and

Table 1. Sustainability Factors in Retail Business

\begin{tabular}{|c|l|l|}
\hline Environmental & Social & Economic \\
\hline Green Building Design & Human Rights & Shareholder Value \\
\hline Renewable Energy & Diversity & Financial goals \\
\hline Stakeholder Training & Trade Fair & Economic performance \\
\hline Green Product and Partnerships & Fair Competition & \\
\hline Recycling And Waste Reduction & Security & \\
\hline Consumer Trends and Behaviors & Philanthropy & \\
\hline Supply Chain Logistics & & \\
\hline Shipping & & \\
\hline
\end{tabular}

Table 2. Sustainable Value Networks

\begin{tabular}{|c|c|c|}
\hline Renewable Energy & Zero Waste & Sustainable Products \\
\hline Greenhouse gas & Operations & Textile \\
\hline Alternative Fuel & Packaging & Electronics \\
\hline Green Offices & Waste & Food And Agriculture \\
\hline Energy Conservation & & Chemicals \\
\hline Construction and Maintenance & & Jewellery \\
\hline Logistics & & Seafood \\
\hline & & Tile, Ceramic \\
\hline
\end{tabular}


waste. In the context of sustainable products, it is seen that textile, electronics, and food are kept in the foreground.

Table 3. shows that according to the analysis of Migros Co.'s sustainability reports, Migros T.A.Ş. gives high priority to the titles of "Waste", "Food and Agriculture" and "Operations" as value networks. When the sustainability reports between 2016-2020 are examined, it is seen that there is no mention of sustainability value networks as "Jewelry", "Construction and Maintenance", and "Alternative Fuel".

Figure 1. shows that when Migros Co.'s 20162020 sustainability reports are examined, we

Table 3. Sustainable Value Networks Frequencies by Years

\begin{tabular}{|c|c|c|c|c|c|c|}
\hline & 2016 & 2017 & 2018 & 2019 & 2020 & TOTAL \\
\hline Tile, Ceramic & 0 & 1 & 1 & 0 & 0 & 2 \\
\hline Seafood And Livestock & 1 & 3 & 6 & 7 & 8 & 25 \\
\hline Jewellery & 0 & 0 & 0 & 0 & 0 & 0 \\
\hline Chemicals & 0 & 0 & 0 & 0 & 1 & 1 \\
\hline Forest and Paper & 11 & 15 & 19 & 22 & 18 & 85 \\
\hline Food And Agriculture & 25 & 26 & 50 & 87 & 72 & 260 \\
\hline Electronics & 7 & 4 & 6 & 8 & 4 & 2 \\
\hline Textile & 3 & 0 & 0 & 2 & 1 & 6 \\
\hline Packaging & 0 & 1 & 2 & 2 & 3 & 8 \\
\hline Waste & 7 & 1 & 4 & 4 & 6 & 242 \\
\hline Operations & 23 & 15 & 20 & 66 & 44 & 138 \\
\hline Logistics & 3 & 1 & 1 & 3 & 4 & 12 \\
\hline Construction and Maintenance & 0 & 0 & 0 & 0 & 0 & 0 \\
\hline Energy Conservation & 4 & 9 & 4 & 5 & 5 & 27 \\
\hline Green Offices & 0 & 0 & 0 & 0 & 3 & 3 \\
\hline Alternative Fuel & 0 & 0 & 0 & 0 & 0 & 0 \\
\hline Greenhouse gas & 14 & 14 & 13 & 7 & 8 & 56 \\
\hline TOTAL & 138 & 130 & 176 & 233 & 217 & 902 \\
\hline
\end{tabular}

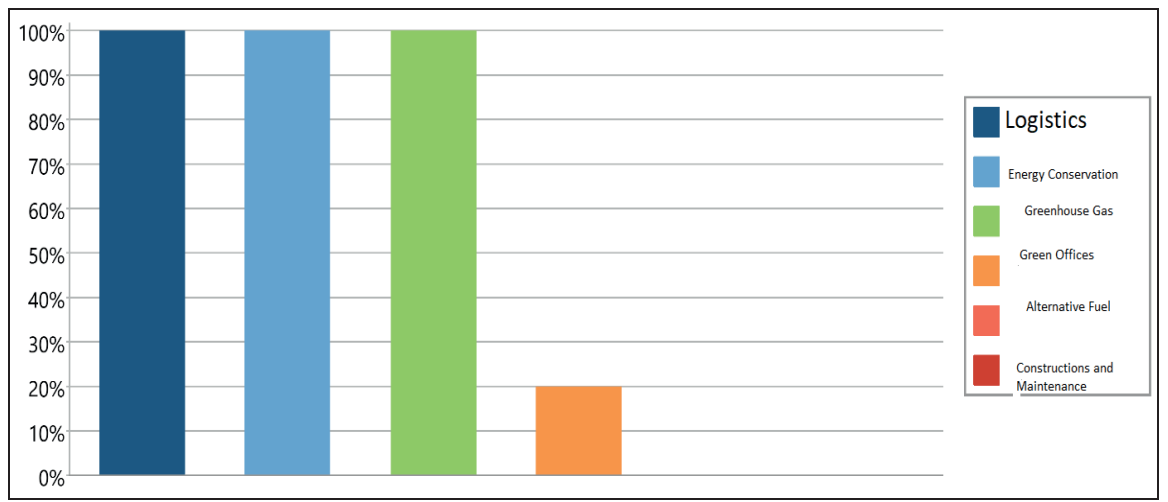

Figure 1. Sustainable Value Networks-Renewable Energy 
see the renewable energy network, which is one of the sub-networks of sustainable value networks. According to Figure 1., the subjects of "Logistics", "Energy Conservation" and "Greenhouse Gas" are given high importance. The importance attached to the subject of "Green Offices" is below 50\%. It is seen that the subjects of "Construction and Maintenance" and "Alternative Fuel" are not included at all.

It is seen in Figure 2. that Migros Co. attaches great importance to the subjects of "Waste", "Operations" and "Packaging". It is noteworthy that among these subjects, especially the waste and operations headings have the highest percentage.

Figure 3. shows the "sustainable products" network, which is one of the subnets of sustainable value networks according to the results obtained from the analysis of Migros Co.'s 2016-2020 sustainability reports. It is seen that especially "Sea products and Livestock",
"Forest and Paper", "Food and Agriculture" and "Electronics" are given high importance. While the subject of "Textile" is given an importance level of $60 \%$, the subjects of "Tile, Ceramics" are given an importance level of less than $40 \%$. The subject of "Chemicals" was mentioned at a level under 30\% and the subject of "Jewelry" was not mentioned at all.

Figure 4. shows that in the context of Migros Co.'s 2016-2020 sustainability reports; A number of measures are taken and planned to reduce greenhouse gas emissions, which is the subnet of the renewable energy value network. Examination of sustainability reports reveals that greenhouse gas emissions have been measured since 2014. Turkey has also declared that by signing the Paris agreement, it will reduce greenhouse gas emissions by up to $21 \%$ by 2030 .

In Figure 5, within the scope of Migros Co.'s 20162020 sustainability reports, there are zero waste and sub-value networks, which are sustainable

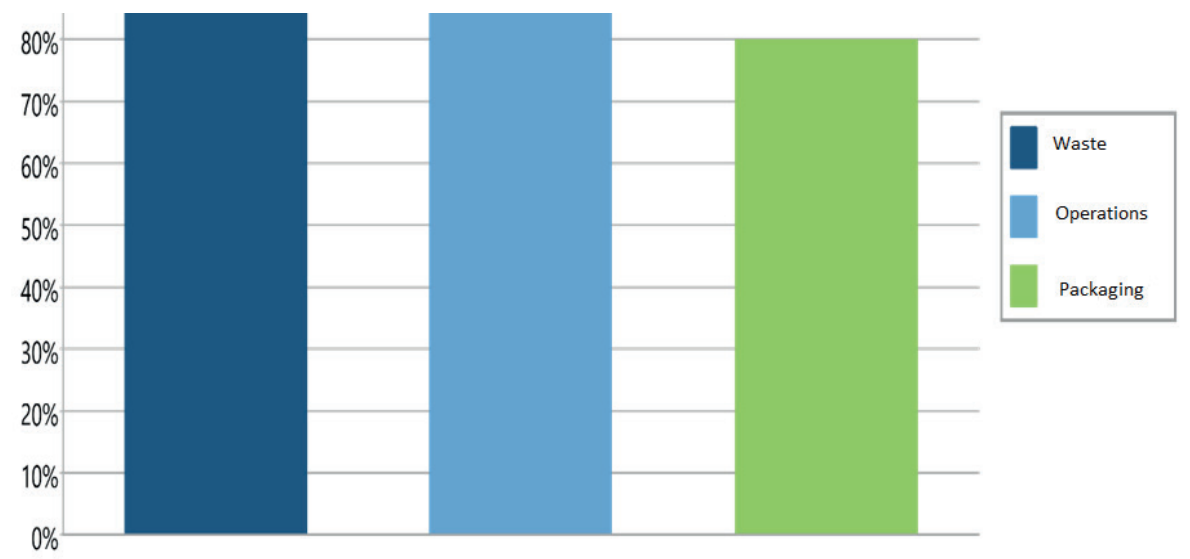

Figure 2. Sustainable Value Networks-Zero Waste

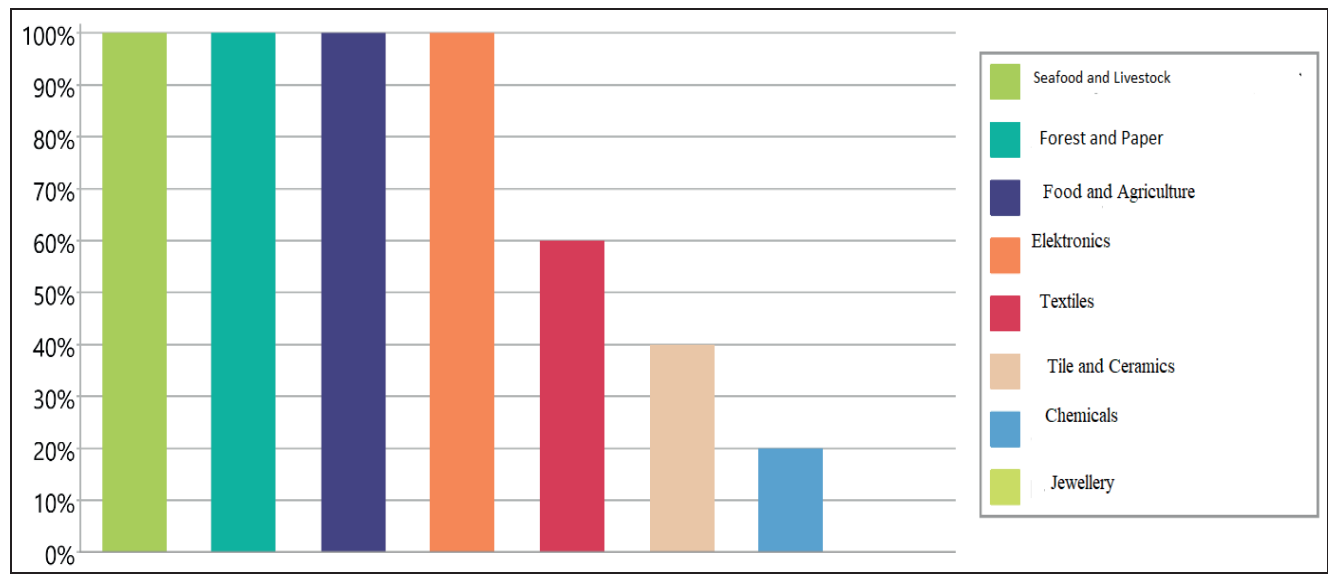

Figure 3. Sustainable Value Networks - Sustainable Products 
value networks. In line with sustainable reporting, importance is given to packaging and it is seen that the shelf life of the products has been extended by $30 \%$ in the stocking. For public health and good quality of life, it can be said that studies have been carried out on the prevention of climate change, reduction of food destruction, waste management, more efficient use of energy and natural resources. This situation becomes more efficient with the operations that set development targets in their sustainable growth strategies.

Figure 6 shows the results of the examination of Migros Co.'s 2016 report as the company's first sustainability report and 2020, as the latest sustainability report as a dual case and it is seen that 12 sub-value networks are included in both the 2016 and 2020 reports. However, 4 different sub-value networks are only included in the 2020 report. According to the high importance of the first three sub-value networks, it is seen that they are listed as "Food and Agriculture", "Waste", and "Operations". In the company's 2020 sustainability report, more emphasis is placed on the subjects of "Packaging", "Green Offices", "Sustainable Products" and "Chemicals".

\section{CONCLUSION}

Today, sustainability stands out as a concept that creates a significant competitive advantage in every field. In particular, sustainable cost management increases business success thanks to the cost efficiency and high financial

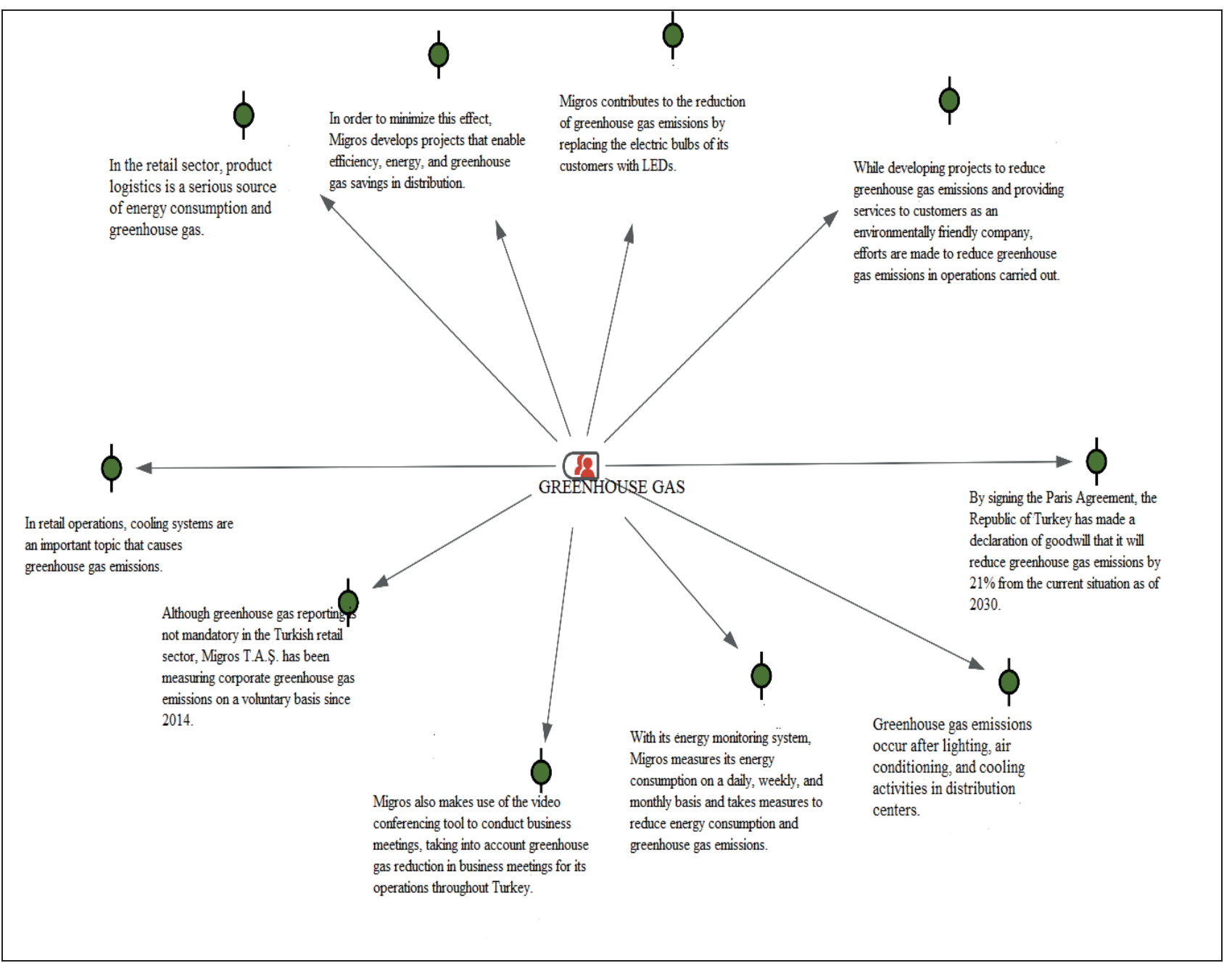

Figure 4. Renewable Energy - Greenhouse Gas Single Case Model 


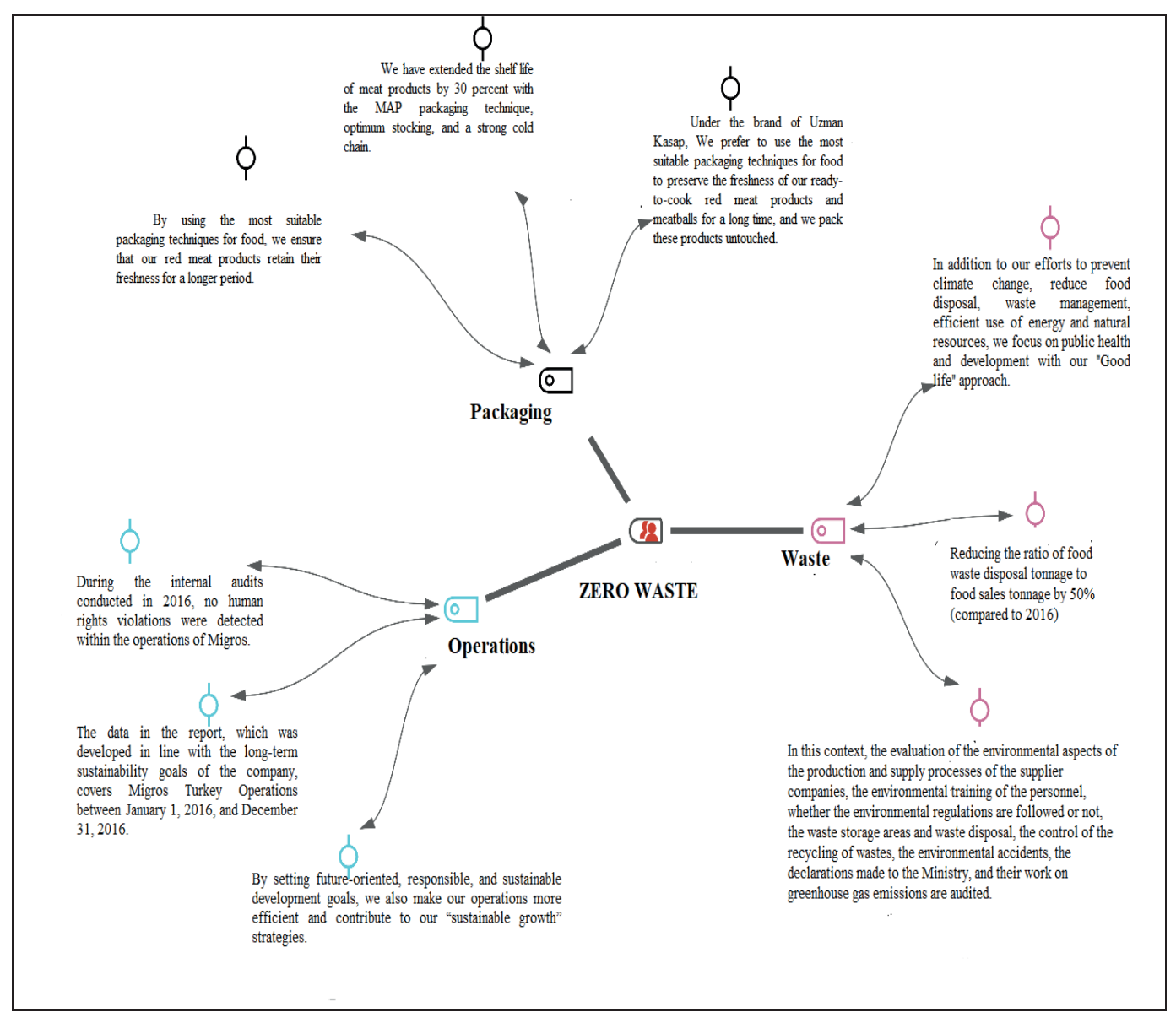

Figure 5. Sustainable Value Networks - Zero Waste Subnets Case Model

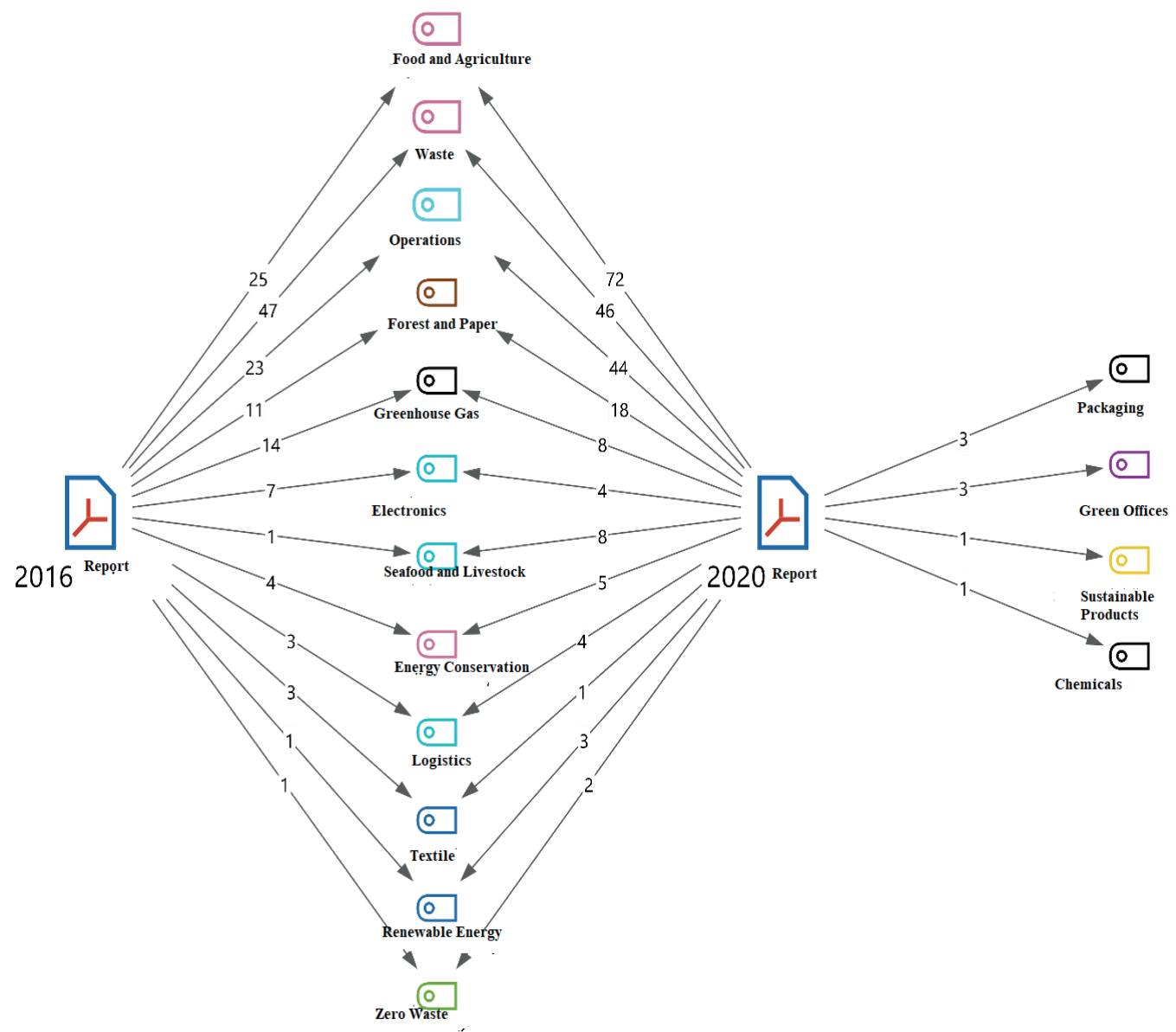

Figure 6. Sustainable Values Network 2016 and 2020 Sustainability Report Dual Case Model 
performance added value it creates for businesses in the global business world. This also applies to the supply chain. Research done in the retail sector, which is an important part of supply chain management shows that there is a significant relationship between sustainable performance and financial performance (Lukic, 2013; Düzer \& Erken, 2018). For this reason, many global companies, especially companies operating in the retail sector, are trying to transform themselves in issues such as energy, environment, and sustainability. In this sense, in companies, the change in issues such as harmonization and reporting of non-financial data, risk management, investor relations management, and reliability of financial and non-financial data is quite high. The importance of explanations about sustainable costs is also increasing in parallel with this change. To sum up, as a result of the analysis made, it can be said that sustainable costs are a very important factor for business success in modern retail, especially during times of economic crisis. In other words, retail business performance is realized with the optimization of sustainable resource costs. Additionally, retailers need to continuously develop their "sustainability awareness" on the importance of more efficient sustainable cost management in order to achieve performance targets (Lukic,2013:268). As a result, by providing a healthy information flow between the suppliers, manufacturers, distributors (wholesalers and retailers), and customers in the supply chain, cost reduction, performance increase, and customer satisfaction will be realized through sustainable cost management. Thus, business success and competitive advantage will be achieved with an integrated -internal and external- cost management perspective in accordance with the new approach. Studies can be conducted on this subject for each link of the supply chain.

\section{REFERENCES}

Akgün, M. (2004). Tedarik Zinciri Yönetiminde Bütünleşik Faaliyet-Tabanlı-Hedef Maliyetleme Yaklaşımı. MODAV Muhasebe Bilim Dünyası Dergisi, Cilt:6, Sayı:1, Mart, 67-88.

Alkan, H. (2001). İşletme Başarısında Maliyet Yönetiminin Rolü Ve Maliyet Yönetiminde Yeni Yaklaşımlar (Ormancılık Açısından Bir Değerlendirme). Turkish Journal Of Forestry, 2(1), 177-192.

Avci, Ç. (2014). Sürdürülebilirlik Açısından Stratejik Maliyet Yönetimi (Master's Thesis, Sosyal Bilimler Enstitüsü), Baybut Üniversitesi Sosyal Bilimler Enstitüsü, İşletme Programı, Eylül, Bayburt.

Chopra S. \& Meindil P., (2007), Supply Chain Management, 3. Baskı, New Jersey, Prentincehall.

Chopra, S., \& Meındl, P., (2004), "Supply Chain Management: Strategy, Planning And Operation", 2. Bask1,

Cooper R. \& Slagmulder R,.(2004), “Interorganizational Cost Management and Relational Context", Accounting, Organizations and Society, Vol.29, (No.1), 1-26.

Deste, M., \& Halifeoğlu, M. (2019). Perakende Ticaret Sektöründeki İşletmelerin Tedarik Zinciri Yönetimi Açısından Finansal Performans Kriterlerinin Belirlenmesi: Bıst'de Bir Uygulama. Bingöl Üniversitesi Sosyal Bilimler Enstitüsü Dergisi, 9(18), 751-774.

Düzer, M., \& Önce, S. (2018). Sürdürülebilirlik Performans Göstergelerine İlişkin Açıklamaların Finansal Performans Üzerine Etkisi: BİST'te Bir Uygulama. Muhasebe Ve Vergi Uygulamaları Dergisi, 11(1), 93-117.

Ellram L.M., (2008), "Integrating Strategic Cost Management With 3DCE Environment: Strategies, Practices and Benefits", Journal of Purchasing and Supply Management, Vol.14, (No.3), 180-191

Eymen, U. E. (2007). Tedarik Zinciri Yönetimi. Kalite Ofisi Yayınları, 15.

Fayard, D., Lee L., Leitch R., \& Kettinger W., (2007), "The Effect of Internal Cost Management, Information Systems Integration, and Absorptive Capacity on Interorganizational Cost Management: A Pilot Study", American Accounting Association - Management Accounting Section Midyear Meeting, Texas, 1-40.

Heizer J. \& Render B.,(1996), Operations management, New Jersey, Prentince Hall.

Jakhar, S.K. (2015). Performance Evaluation And A Flow Allocation Decision Model For A Sustainable 


\section{Supply}

Chain Of An Apparel İndustry. Journal Of Cleaner Production, 87: 391-413

Karakoç, N., Tamer, Eren \& Özcan, E. (2020). Sürdürülebilir Tedarik Zinciri Yönetimi İçin Endüstri 4.0'daki Zorlukların Değerlendirilmesi. Endüstri Mühendisliği Dergisi, 31(2), 215-233.

Karaman, K. (2012). Tedarik Zincirinde Karşılaşılan Problemler Uygulanabilecek İyileştirmeler, Tedarik Zinciri

Karcıoğlu, R. (2000), Stratejik Maliyet Yönetimi Maliyet ve Yönetim Muhasebesinde Yeni Yaklaşımlar, Aktif Yayınevi: Erzurum

Kopczak, L.R. (1997), “Logistics Partnership And Supply Chain Restructuring. Survey Results From The Us Computer İndustry" Production And Operations Management,Vol.6 No.3, Pp.226-247.

Lambert D.M. \& Cooper M., (2000), "Issues in Supply Chain Management", Industrial Marketing Management, Vol.29, (No.1), 65-83.

Lee V. H., Ooi K. B., Chong A. Y. L. \& Sohal A. (2018) The Effects of Supply Chain Management on Technological Innovation: The Mediating Role of Guanxi. International Journal of Production Economics 205(2018): 15-29.

Lee, H.L. \& Billıngton, C. (1992). “Managing Supply Chain İnventory: Pitfalls And Opportunities" Sloan Emanagement Review, 33 (3): 65-73

Li S., Ragu-Nathan B., Ragu-Nathan T. S. \& Rao S. S. (2006) The Impact of Supply Chain Management Practices on Competitive Advantage and Organizational Performance. Omega 34(2): 107-124.

Lukić, R. (2013). Sustainable cost management in retail. Revista de Management Comparat Internațional, 14(2), 268-280.

Lysons, K., 2000, "Purchasing And Supply Chain Management", Addison Wesley, 5.Basım, England.

Migros T.A.Ş Kurumsal Web Sitesi: https://www. migroskurumsal.com/hakkimizda/strateji-vehedefler, Erişim tarihi: 29.11.2021.

Mucuk, İ. (2014), "Pazarlama İlkeleri", 20.Bask1, İstanbul, Türkmen Kitabevi.

Onurlubaş, E. \& Dinçer, D.(2017), “Tüketicilerin Perakende Markalı Ürünlerle İlgili Algısının Belirlenmesi: Antalya İli Örneği", Gümüşhane Üniversitesi Sosyal Bilimler Enstitüsü Elektronik Dergisi, 8(20), Ss. 60-79.

Ortas, E., Moneva, J.M., \& Alvaraz, I. (2014). Sustainable Supply Chain And Company Performance
A Global Examination. Supply Chain Management: An International Journal, 19(3): 332-350.

Otlu, F. \& Karaca, S. (2005). Maliyet Yönetimi Ve Yaşam Seyri Maliyet Analizi. Süleyman Demirel Üniversitesi İktisadi Ve İdari Bilimler Fakültesi Dergisi, 10(2), 245270.

Özdemir, A. İ. (2004). Tedarik Zinciri Yönetiminin Gelişimi, Süreçleri Ve Yararları. Erciyes Üniversitesi İktisadi Ve İdari Bilimler Fakültesi Dergisi, (23).

Özkan, A., \& Aksoylu, S., (2002), “Kaizen Ve Faaliyete Dayalı Maliyetlemenin Birlikte Uygulanabilirligi", Mödav Muhasebe Bilim Dünyası Dergisi, Cilt:4, Sayı:3, Eylül.

Öztürk, D. (2016). Tedarik Zinciri Yönetimi Süreçlerini Etkileyen Faktörler. International Journal Of Social And Economic Sciences, 6(1), 17-24.

Prentice Hall.

Rena, B. E. (2010). Maliyet Yönetimi Tekniklerinin Ve Uygulamalarının Tedarik Zinciri Açısından Değerlendirilmesi. Istanbul Ticaret Üniversitesi Sosyal Bilimler Dergisi Y11:9 Sayı:17 Bahar 2010 S.83-104.

Sarı, İ.U., Ervural, B. Ç., \& Bozat, S. (2017). Sürdürülebilir Tedarik Zinciri Yönetiminde DEMATEL Yöntemiyle Tedarikçi Değerlendirme Kriterlerinin İncelenmesi Ve Sağlık Sektöründe Bir Uygulama. Pamukkale Üniversitesi Mühendislik Bilimleri Dergisi, 23(4), 477-485.

Sevim, Ş., \& Elmacı, O. (2007). Sürdürülebilir Rekabet Üstünlügü Sağlamada Kaynak Tabanlı Yaklaşım Modeli İle Başarı Stratejisinin Belirlenmesinde Lojistik Süreç Maliyetlerinin Analizi. Journal of Azerbayjani Studies, 96-104

Slagmulder, R., (2002), Managing Costs Across the Supply Chain, Seuring S. ve Goldbach M. (Edts.), Cost Management in Supply Chains, (75-87), Germany, Physica-Verlang.

Smith, W. I., \& Lockamy, A. (2000). Target costing for supply chain management: An economic framework. Journal of Corporate Accounting \& Finance, 12(1), 67-77.

Tan, K.C., Kannan, V.R., \& Handfield, R.B. (1998), "Supply Chain Management: Supplier Performance And Firm Performance", International Journal Of Purchasing And Material Management, Vol.34 No.3, Pp.2-9.

Tsai, W.H., \& Hung, S.J. (2009). A fuzzy goal programming approach for green supply chain optimisation under activity-based costing and performance evaluation with a value-chain structure. International Journal of Production Research, 47(18): 
4991-5017.

Türker, M., Yıldırım, F., \& Biçer, A. A. (2005). Üretim Sürecinde Tedarik Zincirinin Önemi Ve Maliyet Yönetimi. V. Ulusal Üretim Arastırmaları Sempozyumu, Stanbul Ticaret Üniversitesi, 25-27 Kasim 2005.

Yağmurlu, N. (2009), Faaliyet Tabanlı Maliyetleme Ve İnşaat Sektöründe Bir Uygulama, Isparta: Süleyman Demirel Üniversitesi. Sosyal Bilimler Enstitüsü. İşletme Anabilim Dalı, Isparta.

Yalçın, S. (2006), “Rekabet Avantajı Sağlamada Stratejik Maliyet Yönetiminin Muhasebe Uygulamalariyla İlişkileri", Dumlupınar Üniversitesi, Sosyal Bilimler Dergisi, s. 15, Ağustos.

Yao, K., \& Liu, C. (2006). An İntegrated Approach For Measuring Supply Chain Performance. Journal Of Modern Accounting And Auditing, 2(10), 17-22.

Yıldırım, S. (2009). İşletmelerde Tedarik Zinciri Yönetimi Ve Toplam Kalite Yönetimi İlişkisi. Süleyman Demirel Üniversitesi Vizyoner Dergisi, 1(1), 175-191.

Yönetimi.https://tedarikzinciri.wordpress.com/ category/ Tedarik-Zinciri-Yonetimi-Toplam-KaliteYonetimi/ (Erişim Tarihi:01.01.2016). 